\title{
A SUPPLEMENT TO MOLECULAR DATA FOR FIVE FREE-LIVING MARINE NEMATODE SPECIES OF THE FAMILY COMESOMATIDAE FILIPJEV, 1918 (NEMATODA: CHROMADORIDA) FROM NORTH VIETNAM
}

\author{
Nguyen Dinh Tu ${ }^{1 *}$, Nguyen Thanh Hien ${ }^{1}$, Nguyen Vu Thanh ${ }^{1}$, \\ Phan Ke Long ${ }^{2}$, A. V. Tchesunov Alexei ${ }^{3}$ \\ ${ }^{1}$ Institute of Ecology and Biological Resources, VAST, *ngdtu@yahoo.com \\ ${ }^{2}$ Vietnam National Museum of Natural, VAST \\ ${ }^{3}$ Moscow Lomonosov State University, Russia
}

\begin{abstract}
Five species of Comesomatidae: Dorylaimopsis halongensis, Hopperia dolichurus, Paracomesoma lissum, Sabatieria doancanhi and Sabatieria praedatrix were identified based on morphological characters of males. To expose the systematic position of these comesomatids, we obtained nucleotide sequences of nuclear ribosomal DNA (D2/D3 and ITS region). The results showed the clear molecular differences between species in the Comesomatidae that proved to the morphology data.
\end{abstract}

Keywords: Comesomatidae, D2D3, ITS, marine nematodes, Ba Lạt.

\section{INTRODUCTION}

The systematics of Comesomatidae was reviewed by several authors as de Coninck (1965) [1]; Vitiello (1969) [19]; Jensen (1979) [11]; Platt (1985) [16]; Lorenzen (1994) [14]; Smolyanko \& Belogurov (1991) [17] and Hope \& Zhang (1995) [10]. According to Jensen (1979) [11] the Comesomatidae included three subfamilies, such as Sabatierinae Filipjev, 1934; Dorylaimopsinae de Coninck, 1965 and Comesomatinae Filipjev, 1918. In a molecular comparison of the D3 expansion segment (26/28S ribosomal RNA gene), Litvaitis et al. (2000) [12] concluded that the Comesomatidae comprised a sister group to the Monhysterida, yet they placed them in the Chromadorida because they considered their molecular trees to be equivocal. In a recent review of nematode systematic position conducted by De Ley and Blaxter (2004) [2] and based on new results on combining morphological and molecular characteristics and phylogeny evaluation of the Comesomatids these authors assigned Comesomatidae to the order Areolaimida. In this paper, first results combining morphological traits and molecular characteristics of four marine species of the family Comesomatidae family recently described in Vietnam, Dorylaimopsis halongensis Nguyen Dinh Tu et al., 2008, Hopperia dolichurus Gagarin \&
Nguyen Vu Thanh, 2006, Paracomesoma lissum Gagarin \& Nguyen Vu Thanh, 2009, Sabatieria doancanhi Nguyen Dinh Tu et al., 2008 and one Sabatieria praedatrix de Man, 1907 are presented.

\section{MATERIALS AND METHODS}

Sampling: Sediment samples from intertidal area in the Xuan Thuy national park areas in 2011 and 2012 were taken by PONNAR grab $(20 \mathrm{~cm} \times 20 \mathrm{~cm}$ surface $)$. Sediment from each site was taken with a depth of $10 \mathrm{~cm}$ with Perspex core $(3.5 \mathrm{~cm}$ in diameter and $40 \mathrm{~cm}$ in length) and immediately fixed in DESS solution (dimethylsulfoxide (20\%) diluted in distilled water, with EDTA salt 0.25 m, $\mathrm{NaOH}$ and saturated with $\mathrm{NaCl}$ ).

Sample processing: Sediment was sieved through $1 \mathrm{~mm}$ mesh size (to separate the coarse shells and plant remains from the sediment). The samples then were rinsed with tap water in a 5 liter beaker. After settlement (10 seconds) the supernatant was poured through a $63 \mu \mathrm{m}$. The rinsing and decantation were repeated 3 times until the water became clear.

After decantation, the sample consisting of a small amount of material was carefully washed bringing the extracted portion of the sediment to one side of the sieve. Then it was washed into a large beaker using LUDOX TM50 specific gravity of $1.18 \mathrm{~g} / \mathrm{ml}$. At least 3 times the sample 
volume of Ludox solution was added, and stirred. Then it was left to settle for at least 40 minutes. Finally, the supernatant was carefully poured through a $40 \mu \mathrm{m}$ sieve. This process was repeated 3 times. The extracted nematodes was washed thoroughly with tap water and then preserved with DESS solution in a suitable container.

Nematode isolation and vouchering: Identification of species and genera was done by an expert nematode taxonomist using an Axioscope Plus II research microscope. Digital photographic vouchers representing head, body surface and tail regions of each specimen were taken at small, intermediate and immersion oil magnification. Immediately after the vouchering procedure, nematodes were collected from the temporary slide, put in lysis buffer and stored at $-20^{\circ} \mathrm{C}$ until further processing.

Molecular analyses of captured specimens: DNA extraction: Immediately after vouchering, DNA was extracted by cutting each nematode into several pieces in $20 \mu \mathrm{l}$ of Worm Lysis Buffer $(50 \mathrm{mM} \mathrm{KCl}, 10 \mathrm{mM}$ Tris-HCl pH 8.3, $2.5 \mathrm{mM} \mathrm{MgCl} 2,0.45 \% \mathrm{NP}, 0.45 \%$ Tween $20)$, transferring them to one or two sterile 0.5$\mathrm{mL}$ centrifuge tubes and digesting them for $1 \mathrm{~h}$ at $65^{\circ} \mathrm{C}$ and for $10 \mathrm{~min}$ at $95^{\circ} \mathrm{C}$ with $2 \mu \mathrm{l}$ of Proteinase K $(10 \mathrm{mg} / \mathrm{ml})$. Tubes were centrifuged at maximal speed $(20817 \mathrm{~g})$ for $1 \mathrm{~min}$ and stored at $80^{\circ} \mathrm{C}$.
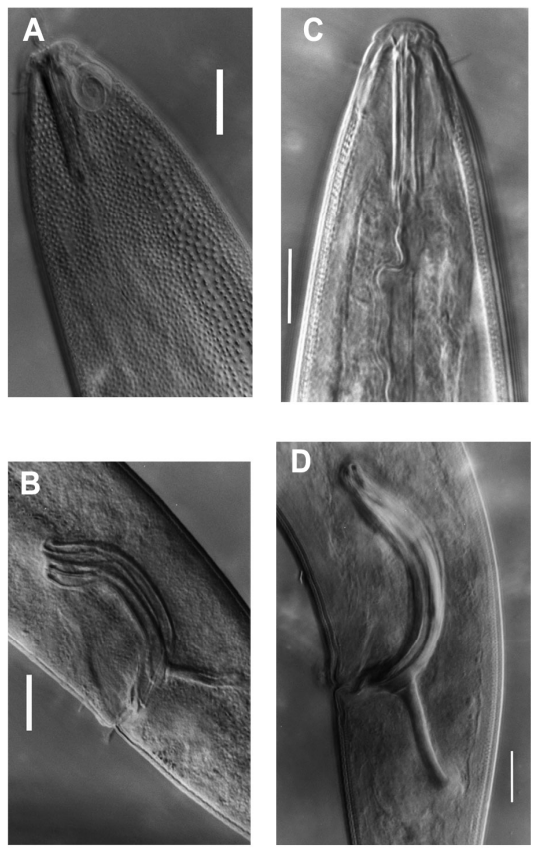
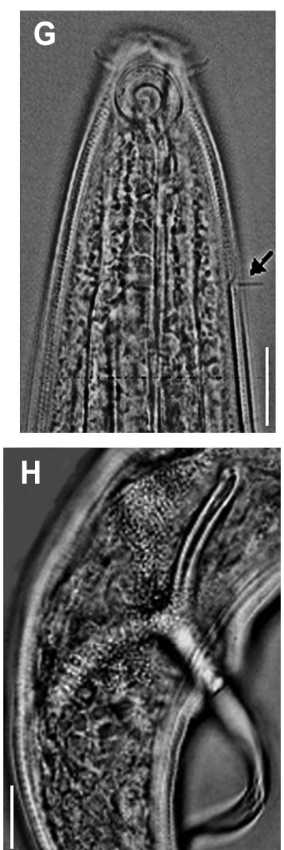
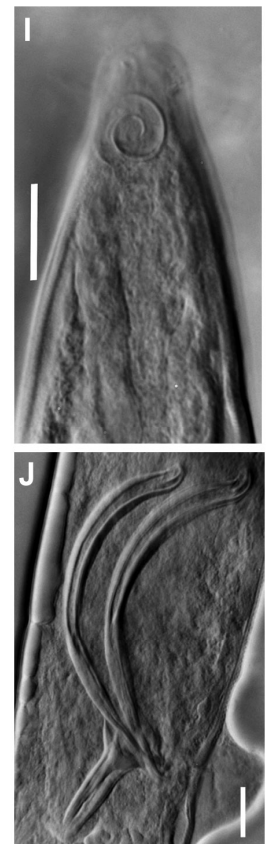

Figure 1. Head and spicule region of a male of Dorylaimopsis halongensis Nguyen Dinh Tu et al., 2008 (A, B), Hopperia dolichurus Gagarin \& Nguyen Vu Thanh, 2006 (C, D), Paracomesoma lissum Gagarin \& Nguyen Vu Thanh, 2009 (E, F), Sabatieria doancanhi Nguyen Dinh Tu et al., 2008 (G, H) and Sabatieria praedatrix de Man, 1907 (I, J).

Scale bars: A- E, G - J = $10 \mu \mathrm{m} ; \mathrm{F}=50 \mu \mathrm{m}$.

PCR for phylogenetic analyses: The D2D3 region of the $28 \mathrm{~S}$ ribosomal subunit was amplified with primers D2A (5'- ACA AGT ACC GTG AGG GAA AGT TG) and D3B (3' TCC TCG GAA GGA ACC AGC TAC TA) as in Derycke et al. (2008) [2]. The Toptaq PCR mix was used, and thermocycling conditions were: $94^{\circ} \mathrm{C}$ for $5 \mathrm{~min} ; 35$ cycles of $94^{\circ} \mathrm{C}$ for $30 \mathrm{~s}$, $56^{\circ} \mathrm{C}$ for $30 \mathrm{~s}$ and $72^{\circ} \mathrm{C}$ for $2 \mathrm{~min}$; and $72^{\circ} \mathrm{C}$ for $10 \mathrm{~min}$. A fragment of the ITS region of the $28 \mathrm{~S}$ ribosomal subunit was amplified with primers Vrain 2F (5' - CTT TGT ACA CAC CGC CCG 
TCG CT) and Vrain 2R (3'- TTT CAC TCG CCG TTA CTA AGG GAA TC) as in Derycke et al. (2008) [2]. The Toptaq PCR mix was used, and thermocycling conditions were: $94^{\circ} \mathrm{C}$ for 5 min; 35 cycles of $94^{\circ} \mathrm{C}$ for $30 \mathrm{~s}, 56^{\circ} \mathrm{C}$ for $30 \mathrm{~s}$ and $72^{\circ} \mathrm{C}$ for $45 \mathrm{~s}$; and $72^{\circ} \mathrm{C}$ for $10 \mathrm{~min}$.

Data analysis: Sequences of comesomatid species from Vietnam were aligned using Clustal X 1.64. Equally weighted maximum parsimony (MP) analysis was performed using PAUP* (4.0 beta version). A heuristic search procedure was used with the following settings: ten replicates of random taxon addition, treebisection reconnection branch swapping, multiple trees retained, no steepest descent, and accelerated transformation. Gaps were treated as missing data. Bootstrap analysis was carried out with 100 replicates.

\section{RESULTS AND DISCUSSION}

Morphological data and DNA sequence data were obtained for five comesomatid species, Dorylaimopsis halongensis Nguyen Dinh Tu et al., 2008; Hopperia dolichurus Gagarin \& Nguyen Vu Thanh, 2006; Paracomesoma lissum Gagarin \& Nguyen Vu Thanh, 2009; Sabatieria doancanhi Nguyen Dinh Tu et al., 2008 and Sabatieria praedatrix de Man, 1907.

Table 1.Morphometric data and accessions number on GenBank of the five species of the family Comesomatidae from Vietnam (all measurements in $\mu \mathrm{m}$ except ratios)

\begin{tabular}{|l|c|c|c|c|c|}
\hline \multirow{2}{*}{$\begin{array}{c}\text { Accessions number } \\
\text { on GenBank }\end{array}$} & $\begin{array}{l}\text { Dorylaimopsis } \\
\text { halongensis }\end{array}$ & $\begin{array}{l}\text { Hopperia } \\
\text { dolichurus }\end{array}$ & $\begin{array}{l}\text { Paracomes } \\
\text { oma lissum }\end{array}$ & $\begin{array}{l}\text { Sabatieria } \\
\text { doancanhi }\end{array}$ & $\begin{array}{l}\text { Sabatieria } \\
\text { praedatrix }\end{array}$ \\
\cline { 2 - 6 } & JX040634 & JX512280 & JX512278 & JX512281 & JX512279 \\
\hline Species measurement (Max - Min; $\mathrm{n}=3$ ) \\
\hline Total body length & $2057-2098$ & $2150-2301$ & $1468-1504$ & $2135-2276$ & $2786-2957$ \\
\hline a & $57.5-58.8$ & $48.0-51.0$ & $32.4-33.6$ & $46.6-47.7$ & $57.5-61.6$ \\
\hline b & $6.6-9.9$ & $11.4-12.0$ & $9.0-9.2$ & $11.0-12.0$ & $9.2-9.6$ \\
\hline c & $5.5-5.7$ & $9.5-10.6$ & $10.0-10.1$ & $14.3-16.0$ & $11.1-12.6$ \\
\hline c' & $13.7-14.7$ & $6.2-6.7$ & $4.6-4.9$ & $3.2-3.6$ & $4.8-5.5$ \\
\hline Head diameter & $10-11$ & $10.2-12$ & $8.2-9$ & $12.5-14.5$ & $12.6-14.1$ \\
\hline Cephalic setae & $4.8-5$ & $4.2-4.5$ & $6.8-7.5$ & $5-5.3$ & $4.8-5.6$ \\
\hline Amphid width & $8.5-10.2$ & $10.8-11.3$ & $10.3-11$ & $8.6-9.8$ & $7.8-8.4$ \\
\hline Pharynx length & $211.5-312$ & $189-196$ & $159-167$ & $184.5-199.2$ & $289-318$ \\
\hline $\begin{array}{l}\text { Maximal } \\
\text { diameter }\end{array}$ & $35-36.5$ & $44.8-45.2$ & $44.8-45.3$ & $45.8-47.7$ & $47.9-49.8$ \\
\hline Spicule length & $45.3-46.8$ & $56.2-57.1$ & $95.6-98.3$ & $89.9-92.4$ & $64-69$ \\
\hline Gubernaculum length & $14.5-16.1$ & $21.1-22.5$ & $23.5-26.1$ & $41.2-43.3$ & $32.4-35.2$ \\
\hline Tail length & $368.5-375.6$ & $215-226$ & $146-150$ & $142.4-149.8$ & $235-256$ \\
\hline Anal diameter & $25.6-27$ & $33.6-34.8$ & $30.6-32.8$ & $41.6-45.2$ & $46.5-49.3$ \\
\hline
\end{tabular}

\section{Sequence analyses of D2/D3 region}

The D2D3 region of species in the family Comesomatidae ranged from 721 bp (P. lissum) to $738 \mathrm{bp}$ ( $S$. doancanhi) in which species in the
Sabatieria genus ranged from 735bp (S. praedatrix) to $738 \mathrm{bp}$ ( $S$. doancanhi) (table 2). The D2D3 region exhibited the base composition as follow: A - 24 (21-27), C - 24 (21-28), G - 32 (28-35), T - 20 (16-24). 

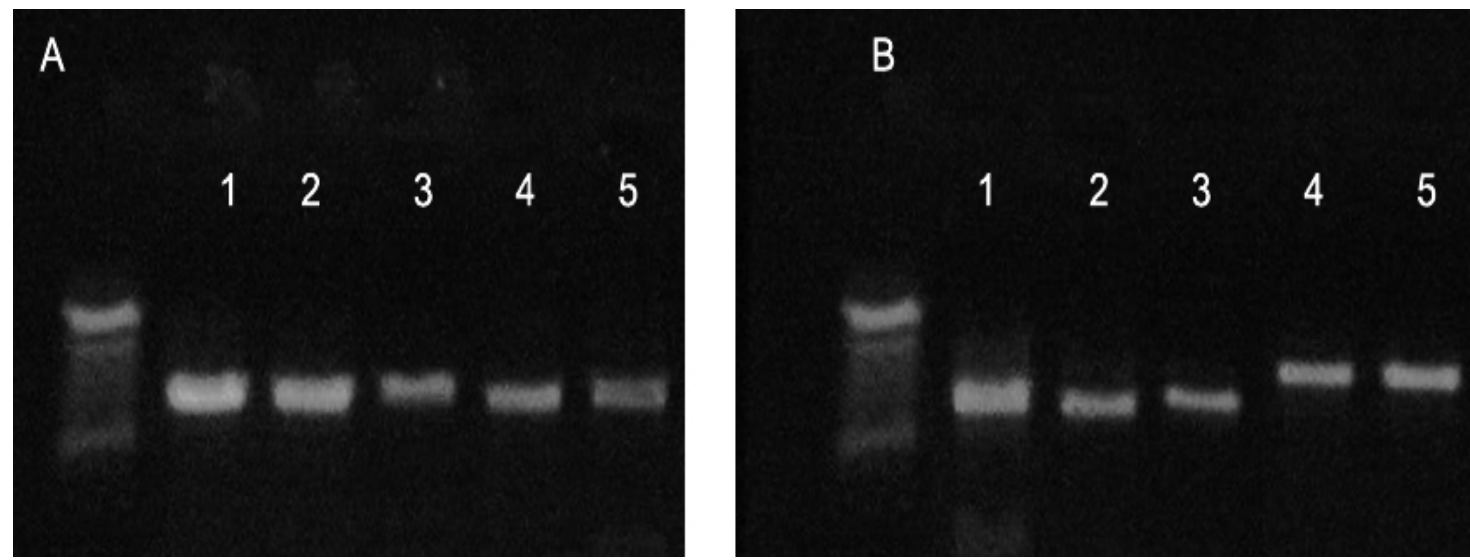

Figure 2. PCR product of amplified D2D3 (A) and ITS (B) region of Dorylaimopsis halongensis (lane 1), Hopperia dolichurus (lane 2), Paracomesoma lissum (lane 3), Sabatieria doancanhi (lane 4) and Sabatieria praedatrix (lane 5).

Table 2. The base composition and the length of the D2D3 region of the species in the family Comesomatidae in Vietnam

\begin{tabular}{|l|c|c|c|c|c|}
\hline \multirow{2}{*}{ Species } & \multicolumn{4}{c|}{ Base composition (\%) } & \multirow{2}{*}{ D2D3 length (bp) } \\
\cline { 2 - 5 } & $\mathrm{A}$ & $\mathrm{C}$ & $\mathrm{G}$ & $\mathrm{T}$ & 731 \\
\hline D. halongensis & 23 & 23 & 32 & 22 & 735 \\
\hline S. praedatrix & 21 & 28 & 35 & 16 & 738 \\
\hline S. doancanhi & 23 & 26 & 35 & 17 & 721 \\
\hline P. lissum & 27 & 21 & 28 & 24 & 730 \\
\hline H. dolichurus & 26 & 23 & 30 & 22 & 731 \\
\hline Average & 24 & 24 & 32 & 20 & \\
\hline
\end{tabular}

Table 3. Pairwise distance between species in the Comesomatidae family in Vietnam based on D2D3 sequences (below diagonal: total character differences, above diagonal: mean character differences adjusted for missing data)

\begin{tabular}{|c|l|c|c|c|c|c|}
\hline No & Species & 1 & 2 & 3 & 4 & 5 \\
\hline 1 & H. dolichurus & - & 21.0 & 30.9 & 28.3 & 16.7 \\
\hline 2 & S. praedatrix & 153 & - & 28.5 & 13.0 & 19.3 \\
\hline 3 & P. lissum & 221 & 204 & - & 32.9 & 31.3 \\
\hline 4 & S. doancanhi & 205 & 95 & 235 & - & 26.3 \\
\hline 5 & D. halongensis & 122 & 141 & 224 & 191 & - \\
\hline
\end{tabular}

S. doancanhi differed from $S$. praedatrix by 95 nucleotides. $P$. lissum differed from $S$. doancanhi by 235 nucleotides. The divergence between taxa ranged from 13-32.9\% (table 3 ).

The MP analysis of D2D3 region indicated that among 750 characters, 127 were parsimony informative and obtained a single tree (tree length $=750$ ) (fig 3). S. praedatrix clustered with $S$. doancanhi with high bootstrap support (100\%) and had sister relationship with P. lissum (bootstrap 98\%). 


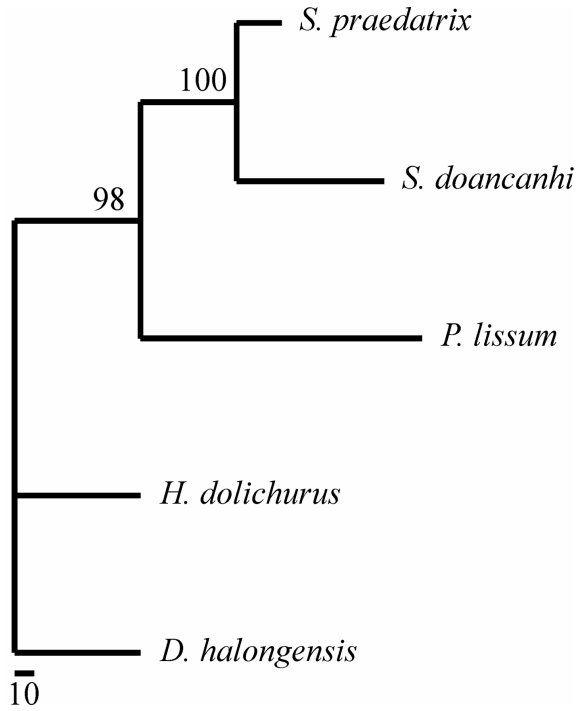

Figure 3. The phylogenetic relationship of species in the Comesomatidae family in Vietnam based on D2D3 sequences. The single MP tree (tree length $=750$ )

\section{Sequence analyses of ITS region}

The length of partial 18S, ITS1, 5.8S, ITS2 and partial $28 \mathrm{~S}$ of species in the Comesomatidae family ranged from $837 \mathrm{bp}(P$. lissum) to $861 \mathrm{bp}$ ( $S$. praedatrix); the species in the genus Sabatieria were 856bp (S. doancanhi) and 861 bp (S. praedatrix) (table 4).

The Adenine composition in the ITS region

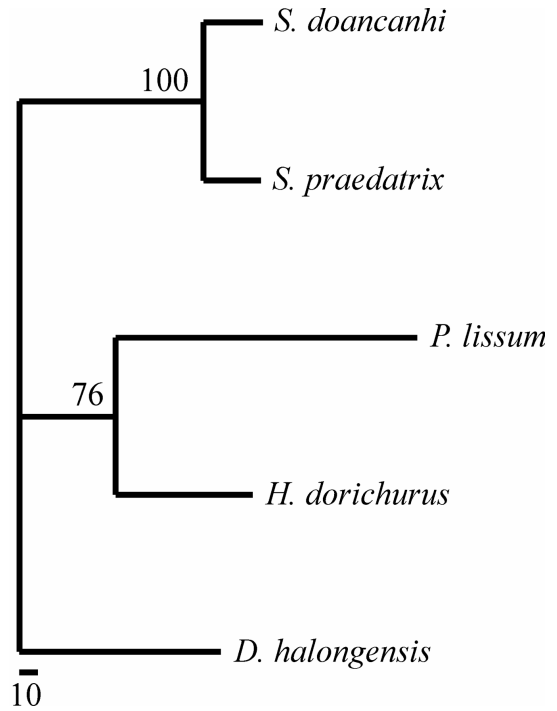

Figure 4. The phylogenetic relationship of species in the Comesomatidae in Vietnam based on ITS sequences. The single unrooted tree (tree length $=874)$

of species in the Comesomatidae family ranged from 22\% (S. doancanhi) to 28\% (P. lissum); Cytosine composition was lowest in $P$. lissum (22\%), highest in $S$. doancanhi and $S$. praedatrix (28\%); Guanine composition was lowest in $P$. lissum (24\%), highest in $S$. praedatrix (31\%); Thymine composition was lowest in S. praedatrix (19\%), highest in $P$. lissum (26\%) (table 4).

Table 4. The base composition and the length of partial 18S-ITS1-5.8S-ITS2-28S partial of the species in the Comesomatidae family in Vietnam

\begin{tabular}{|l|c|c|c|c|c|}
\hline \multirow{2}{*}{ Species } & \multicolumn{4}{|c|}{ Base composition (\%) } & \multirow{2}{*}{$\begin{array}{c}\text { ITS length } \\
\text { (bp) }\end{array}$} \\
\cline { 2 - 5 } & A & C & G & T & 858 \\
\hline D. halongensis & 24 & 27 & 27 & 23 & 856 \\
\hline S. doancanhi & 23 & 28 & 30 & 20 & 861 \\
\hline S. praedatrix & 22 & 28 & 31 & 19 & 837 \\
\hline P. lissum & 28 & 22 & 24 & 26 & 841 \\
\hline H. dorichurus & 26 & 25 & 25 & 24 & 850.6 \\
\hline Average & 24 & 26 & 28 & 23 & \\
\hline
\end{tabular}

Two species in the Sabatieria genus $(S$. doancanhi và $S$. praedatrix) had lowest divergence $(7.1 \%)$ that equivalent to 61 nucleotides. The highest divergence was $30.8 \%$ between $P$. lissum and $D$. halongiensis (255 nucleotides). $H$. dolichurus had lowest divergence $(20.8 \%)$ compare with $D$. halongiensis (173 nucleotides) and highest divergence $(28.1 \%)$ compare with $P$. lissum (233 nucleotides). 
Table 5. Pairwise distance between species in the Comesomatidae family in Vietnam based on ITS sequences (below diagonal: total character differences, above diagonal: mean character differences adjusted for missing data)

\begin{tabular}{|c|l|c|c|c|c|c|}
\hline No & \multicolumn{1}{|c|}{ Species } & 1 & 2 & 3 & 4 & 5 \\
\hline 1 & D. halongensis & - & 23.9 & 23.4 & 30.8 & 20.8 \\
\hline 2 & S. doancanhi & 202 & - & 7.1 & 29.7 & 23.8 \\
\hline 3 & S. praedatrix & 199 & 61 & - & 29.5 & 23.7 \\
\hline 4 & P. lissum & 255 & 246 & 246 & - & 28.1 \\
\hline 5 & H. dorichurus & 173 & 198 & 199 & 233 & - \\
\hline
\end{tabular}

Maximum Parsimony (MP) analysis of ITS of species in the Comesomatidae family in Vietnam indicated that among 874 characters, 141 characters were pasimony informative. In the single MP unrooted tree (fig. 4), $S$. praedatrix clustered with $S$. doancanhi (bootstrap 100\%) and H. dolichurus clustered with P. lissum (bootstrap 76\%) and D. halongiensis located in the base of the tree.

Acknowledgements: We thank Vietnam Academy of Science and Technology (VAST) under grant number VAST.ĐL.13/11-12 and VAST.HTQT.NGA.01/2012-2013.

\section{REFERENCES}

1. De Coninck L. A., 1965. Classe des Nématodes - Systématique des Nématodes et sous-classe des Adenophorea. - In: Grassé, P.-P. (ed.): Traité de Zoologie, 4(2): 586-681.

2. De Ley P., Blaxter M., 2004. A new system for Nematoda: combining morphological characters with molecular trees, and translating clades into ranks and taxa. Nematology Monographs and Perspectives, 2: 633-653.

3. de Man J. G., 1907. Sur quelques espèces nouvelles ou peu connues de nématodes libres habitant les côtes de la Zélande Mém. Soc. Zool. Fr., 20: 33-90.

4. Derycke S., Fonseca G., Vierstraete A., Vanfleteren J., Vincx M., Moens T., 2008. Disentangling taxonomy within the Rhabditis (Pellioditis) marina (Nematoda, Rhabditidae) species complex using molecular and morphological tools. Zoological Journal of the Linnean Society, 152: 1-15.
5. Gagarin V. G., Nguyen Vu Thanh, 2006. Three new species of free-living nematodes of the family Comesomatidae from the Mekong River, Vietnam (Nematoda, Monhysterida). Zoosystematica Rossica, 15(2): 221-228.

6. Gagarin V. G., Nguyen Vu Thanh, 2006. Three new species of the genus Hopperia (Nematoda, Comesomatidae) from mangroves of the Mekong river delta (Vietnam). Zhuologischeskyi Journal, 85(1): 18-27.

7. Gagarin V. G., Nguyen Vu Thanh, 2009. Three new species of free-living nematodes from of Mekong Mekong River, Vietnam. International Journal of Nematology, 19(1): 7-15.

8. Heip C., Vincx M., Vranken G., 1985. The ecology of marine nematodes. Oceanography and Marine Biology. Annual Review. London, 23: 399-489.

9. Hompson J. D., Gibson T. J., Plewniak F., Jeanmougin F., Higgins D. G., 1997. The ClustalX windows interface: flexible strategies for multiple sequence alignment aided by quality analysis tools. Nucleic Acids Research, 24: 4876-4882.

10. Hope W. D., Zhang Zhi-Nan, 1995. New nematode from the Yellow Sea, Hopperia hexadentata n.sp. and Cervonema deltentis n.sp. (Chromadorida: Comesomatidae), with observations on morphology and systematic. Invertebrate Biology, 114(2): 119-138.

11. Jensen P., 1979. Revision of Comesomatidae//Zoologica Scripta, 8(2): 81-105.

12. Litvaitis M. K., Bates J. W., Hope W. D., 
Moens T., 2000. Inferring a classification of the Adenophorea (Nematoda) from nucleotide sequences of the D3 expansion segment (26/28S rDNA). Canadian Journal of Zoology, 78: 911-922.

13. Livaitis M. K., Bates J. W., Hope W. D., Moens T., 2000. Inferring a classification of the Adenophorea (Nematoda) from nucleotide sequences of the D3 expansion segment (26/28SrDNA). Canadian Journal of Zoology, 78: 911-922.

14. Lorenzen S., 1994. The Phylogenetic Systematics of Free-living Marine Nematodes. Ray Society, London.

15. Nguyen Dinh Tu, Nguyen Vu Thanh, Nic Smol, Ann Vareusel, 2008. Two new marine species of the family Comasomatidae Filipjev, 1918 (Nematoda: Chromadorida) from Ha Long Bay, Vietnam. TAP CHI SINH HOC, 30(1): 12-21.

16. Platt H. M., 1985. The freeliving marine nematode genus Sabatieria (Nematoda:
Comesomatidae). Taxonomic revision and pictorial keys. Zoological Journal of the Linnean Society, 83: 27-78.

17. Smolyanko O. I., Belogurov O. I., 1991. Description and taxonomic position of Expressonema grandulata gen. et sp. n. and structural analysis of the family Dorylaimopsidae (Nematoda, Comesomatoidea). Zoologicheskii Zhournal, 770(5): 117-127.

18. Swofford D. L., 1998. PAUP* Phylogenetic analysis using parsimony. Version 4. Sinauer, Sunderland, MA. 128 pp.

19. Vitiello P., 1969. Hopperia, nouveau genre de Nématode libre marin (Comesomatidae). Téthys, 1: 485-491.

20. Yoder M., De Ley I. T., King I. W., MundoOcampo M., Mann J., Blaxter M., Poiras L., De Ley P., 2006. DESS: a versatile solution for preserving morphology and extractable DNA of nematodes. Nematology, 8: 367376.

\title{
ĐặC ĐIỂM PHÂN TỬ CỦA NĂM LOÀI TUYẾN TRÙNG BIỂN SỐNG TỬ DO THUỘC HỌ COMESOMATIDAE FILIPJEV, 1918 (NEMATODA: CHROMADORIDA) Ở MIỀN BẮC VIẸTT NAM
}

\author{
Nguyễn Đình Tứ ${ }^{1}$, Nguyễn Thanh Hiền ${ }^{1}$, Phan Kế Long ${ }^{2}$, \\ A. V. Tchesunov Alexei ${ }^{3}$, Nguyễn Vũ Thanh ${ }^{1}$ \\ ${ }^{1}$ Viện Sinh thái và Tài nguyên Sinh vật, Viện Hàn lâm KH \& CN Việt Nam \\ ${ }^{2}$ Bảo Tàng thiên nhiên Việt Nam, Viện Hàn lâm KH \& CN Việt Nam \\ ${ }^{3}$ Đại học tổng hợp quốc gia mang tên Lômônôxop (MGU), Matxcova, CHLB Nga
}

\section{TÓM TÁT}

Năm loài tuyến trùng biển sống tự do ở vùng nước ven bờ ở các tỉnh phía Bắc Việt Nam là những phát hiện mới cho khu hệ Việt Nam và đã được mô tả gần đây là các loài: Dorylaimopsis halongensis Nguyen Dinh Tu et al., 2008; Hopperia dolichurus Gagarin \& Nguyen Vu Thanh, 2006; Paracomesoma lissum Gagarin \& Nguyen Vu Thanh, 2009; Sabatieria doancanhi Nguyen Dinh Tu et al., 2008 và Sabatieria praedatrix de Man, 1907 dựa trên các đặc trưng cơ bản về các sai khác rất lớn trong hình thái học của chúng với các loài đã biết. Nhằm xác định chính xác vị trí phân loại của các loài tuyến trùng nói trên trong phả hệ của nhóm tuyến trùng Comesomatids, chúng tôi đã tiến hành các nghiên cứu chuỗi đặc trưng phân tử nhóm nucleotides ribosome DNA (D2/D3 28S và ITS). Kết quả nghiên cứu về sinh học phân tử một lần nữa khẳng định các loài bắt gặp ở Việt Nam hoàn toàn là ghi nhận mới và khác biệt so với các loài đã biết trong họ Comesomatidae

Tù khóa: Comesomatidae, D2D3, ITS, tuyến trùng biển, Ba Lạt.

Ngày nhận bài: 9-1-2013 